\title{
Shear Strength of Tack Coat on Flexible Pavement and Composite Pavement
}

\author{
Tampanatu P.F. Sompie \\ Department of Civil Engineering, State Polytechnic of Manado, Manado, INDONESIA \\ tpf_sompie@yahoo.com \\ Syanne Pangemanan \\ Department of Civil Engineering, State Polytechnic of Manado, Manado, INDONESIA \\ upe_sp2000@yahoo.com
}

\begin{abstract}
Tack coat is a thin layer that spread on the surface of existing pavement or concrete pavement. The function of this layer is as an adhesive layer needed to give adhesive power between the existing pavement course and new pavement course or with the concrete pavement, therefore created one strong unity and would bond both, in order to withstand the sheer strength caused by the vehicle load on top of it. Strong adhesiveness of the tack coat course will add sheer strength between the interfaces of the pavement courses. Strong adhesiveness is gained from the asphalt mixed with solvent, therefore created the right viscosity level of the tack coat solution. This research was aimed to measure the sheer strength of tack coat by using modified direct shear asphalt samples. The research method used was by using gauge to measure the sheer strength of tack coat on asphalt sample which was the modified direct shear. While the samples were consisted of 2 types, the asphalt solvent sample as a model of flexible pavement course of AC-WC pavement type with optimum asphalt content of $6.1 \%$, and concrete solvent sample as a model of rigid pavement. These samples were made in briquette form, made with Marshall Mould with 4 inches diameter. The tack coat solvent was made in three solvent variations, which was referring to the standard of the Directorate General of Highways. From this research, it could be concluded that the highest shear strength for flexible pavement was reached on the tack coal solvent mix composition of $30 \mathrm{pph}$ and composite pavement of $15 \mathrm{pph}$. Tack coat spread rate of $0.251 / \mathrm{m}^{2}$ gave highest shear strength on flexible pavement and composition pavement of $0.351 / \mathrm{m}^{2}$. Balance was reached on flexible pavement on tack coat variation of $30 \mathrm{pph}$ and $50 \mathrm{pph}$; while on composite pavement, balance was reached on tack coat solvent variation of $15 \mathrm{pph}$ and $30 \mathrm{pph}$. This modified direct shear sample could be a method to measure shear strength of tack coat on flexible pavement and composite pavement.
\end{abstract}

Keyword: shear strength; tack coat; flexible pavement

\section{INTRODUCTION}

Tack coat is thin layer that spread on the surface of existing pavement or concrete pavement, which functioned as adhesive layer needed to give adhesiveness between existing pavement course and new pavement course or with concrete pavement, to reach a strong uniformity that would withstand shear strength of vehicle load on top of it. The strong adhesiveness of the tack coat layer would add shear strength between the pavement courses interfaces. Strong adhesiveness is gained from asphalt mixed with solvent, therefore created the right viscosity level of the tack coat solution.

Tack coat could be made from rapid setting asphalt emulsion according to AASHTO M 140 (AASHTO, 2016) conditions or from cutback asphalt that fulfilled the conditions of AASHTO M 20 (AASHTO, 1970). Cutback asphalt tack coat is usually used on road construction, which is made from asphalt cement or refinery bitumen that is mixed with kerosene solvent (medium curing type). Asphalt cement is dissolved with 25-30 parts of kerosene per 100 part of asphalt, which usually called as 25-30 pph. Based on the general specification from Public Works Ministry, the Directorate General of Highways (2013) requires the using dose of tack coat is $0.15 \mathrm{l} / \mathrm{m}^{2}-0.35 \mathrm{l} / \mathrm{m}^{2}$ on porous and weather-exposed surface.

\section{TACK COAT}

In general, tack coat is a thin adhesive layer sprayed in between the surface of existing asphalt pavement course and new asphalt pavement course, or between the composite pavements. Tack coat is smelting of liquid asphalt that rapidly evaporate on top of existing pavement course that already paved (Afrilianto, 2007). Tack coat is thin layer of asphalt that gives adhesiveness and strength between the existing pavement course and new pavement course. Tack coat could be made from emulsion asphalt of Rapid Setting type with water diluent and solvent, or from liquid asphalt (cutback asphalt) with solvent that easily evaporated. The distribution quantity of tack coat dose depends on the condition of the existing construction 
surface, started from $0.15-0.35 \mathrm{l} / \mathrm{m}^{2}$ with temperature of $110 \pm 10^{\circ} \mathrm{C}$. The tack coat layer functioned as adhesive layer between the existing pavement course and the new pavement course, in order to give strong adhesiveness. Tack coat layering is conducted by using asphalt distributor or asphalt sprayer, by arranging the nozzle position and height to reach a well-distributed tack coat layer, according to the required distribution dose. The tack coat layer needed to be left for a while to give time for the diluent (water or oil) cutback asphalt or emulsion asphalt to evaporate. The duration for the diluent to evaporate (depends on the weather condition) known as the setting time, or sometimes the curing time. The shear resistance generated by the tack coat on the asphalt layer will increase with the length of the curing time up to a certain time limit. Longer curing time would decrease the resulting shear resistance, this tendency occurs because oil evaporation in the cutback asphalt would cause viscosity changes, thereby making the asphalt harder. If the curing time is too short, the shear resistance would also decrease because the oil in the cutback asphalt created weak bond between the layers interfaces (Rumkita \& Yamin, 2006).

\subsection{Forming Materials of Tack Coat}

Asphalt is defined as black or dark brown coloured material, solid at room temperature, semi-solid and liquid if heated to a certain temperature. Hydrocarbon is the basic main ingredient of asphalt, which is generally called bitumen; therefore, asphalt is also known as bitumen. Composition of asphalt is consisted of asphaltenes and maltenes. Asphaltene is black or dark brown coloured material that does not dissolve in heptane, which is thick liquid that consists of resin and oil. Resin is a yellow or dark brown liquid that gives adhesive trait in asphalt, it is a part that easily lost or diminished during the road service lifetime.

\subsection{Diluent/Solvent Material}

The diluent/solvent material of cutback asphalt consisted of three types, which are:

a) Rapid Curing Cutback (RC), in which the asphalt cement is dissolved with gasoline diluent material. $\mathrm{RC}$ is the fastest evaporating cutback asphalt.

b) Medium Curing Cutback (MC), in which the asphalt cement is dissolved with a thicker diluent material, such as kerosene. This type is widely used, because its' relatively cheap price, and also because kerosene does not quickly evaporate, therefore giving ease of work (workability) and accuracy in researchs.

c) Slow Curing Cutback (SC), in which the asphalt cement is dissolved with a more viscous material such as diesel. This type is the longest evaporating cutback asphalt; therefore it is rarely used in asphalt works.

\section{RESEARCH METHOD}

\subsection{Equipment}

To measure the shear strength of tack coat on asphalt sample, modified direct shear test equipment was used. A Direct shear test equipment used was the same tool used to obtain soil shear parameters; modifications were only done on the proving ring base and the test sample base (shear box), which were adjusted to the test sample size which was 4 inches with height of \pm 7 $\mathrm{cm}$.

\subsection{Test sample}

Test sample in this research consisted of two types, which were 135 pieces of asphalt mix test samples as the model for flexible pavement course, and 45 pieces of concrete mix test sample as the model for rigid pavement. The test sample was made into briquette with Marshall Mould in diameter of 4 inches. The test sample for flexible pavement was made from AC Wearing Course type with optimum asphalt content of $6.1 \%$; and the test sample for flexible pavement was made with compressive strength on age of 28 days, not less than $350 \mathrm{~kg} / \mathrm{cm}^{2}$. In order to provide test sample with condition that resembles the existing pavement condition, aging process was conducted. As quoted from Rumkita and Yamin (2006), the aging process was conducted by inserting the test sample into the oven for 5 days with temperature of $85^{\circ} \mathrm{C}$.

\subsection{Tack Coat Solution}

According to the standard of Directorate General of Highways, tack coat solution is of 25-30 pph with tack coat distribution of $0.15-0.35 \mathrm{l} / \mathrm{m}^{2}$, therefore to obtain a good result, in this research three solution variations were made, which were $15 \mathrm{pph}$ (one level below the standard), $30 \mathrm{pph}$ (standard), and $50 \mathrm{pph}$ (one level above the standard); and the tack coat distribution was $0.15-0.55 \mathrm{l} / \mathrm{m}^{2}$ (two level above the standard dosage). The calculation for tack coat material composition on tack coat solution mix variation of $15 \mathrm{pph}$ is as shown in Table 1, as follows:

Asphalt $=\frac{100}{115} \times 100 \%=86.96 \%$

Kerosene $=\frac{15}{115} \times 100 \%=13.04 \%$

One litre of tack coat solution was needed:

Asphalt $=\frac{86.96}{100} x 1.03=0.8957 \mathrm{~kg}=895.67 \mathrm{gram}$ 
Kerosene $=\frac{13.04}{100} \times 0.8=0.1043 \mathrm{~kg}=104.32 \mathrm{gram}$

Specific gravity (theoretically) $=$

$$
\frac{100}{\frac{13.04}{0.8}+\frac{86.96}{1.03}}=0.993 \mathrm{gr} / \mathrm{cm}^{3}
$$

Table 1. Distribution necessity for tack coat dose of $15 \mathrm{pph}$

\begin{tabular}{llllll}
\hline & 0.15 & 0.25 & 0.35 & 0.45 & 0.55 \\
& $1 / \mathrm{m}^{2}$ & $1 / \mathrm{m}^{2}$ & $1 / \mathrm{m}^{2}$ & $1 / \mathrm{m}^{2}$ & $1 / \mathrm{m}^{2}$ \\
\hline Litre & 0.0012 & 0.0020 & 0.0028 & 0.0036 & 0.0045 \\
$\begin{array}{l}\text { Weight } \\
\text { gram) }\end{array}$ & 1.1916 & 2.0116 & 2.8162 & 3.6208 & 4.4255 \\
\hline
\end{tabular}

\subsection{Testing}

Testing for tack coat shear strength was conducted by using the modified direct shear equipment. The test equipment was placed in the shear box base, the shear box then was being slid manually. The calculation of the vehicle speed and vehicle load as normal load $(\mathrm{N})$ :

Vehicle speed:

Assuming the vehicle speed of $40 \mathrm{~km} / \mathrm{hour}=$

$\frac{40 \times 1.000 .000}{60}=666,666.76 \mathrm{~mm} / \mathrm{min}$

The speed of the shear box of $666,666.67 \mathrm{~mm} / \mathrm{min}$ (666.67 $\mathrm{m} / \mathrm{min})$ could not be applied because of limitation of the direct shear equipment, therefore in this research the shear box speed was set of 10 $\mathrm{mm} / \mathrm{minute}$, so:

$$
\frac{10}{1.000 .000} \times 60=0.0006 \mathrm{~km} / \text { hour }=0.6 \mathrm{~m} / \text { hour }
$$

\subsection{Vehicle Load (N)}

Standard single axle load $=8160 \mathrm{~kg}$ (single axle with dual wheel): Vehicle wheel contact area: 4 units (17x30 $\mathrm{cm})=2040 \mathrm{~cm}^{2}$

Load per $\mathrm{cm}^{2}=\frac{8160}{2040}=4 \mathrm{~kg}$
Test sample area of diameter 4 inch $=81.03 \mathrm{~cm}^{2}$

Test load $=4 \mathrm{~kg} \mathrm{x} 81.03 \mathrm{~cm}^{2}=324.12 \mathrm{~kg}$

Which could not be applied, so normal load (n) of 20 $\mathrm{kg}$ was used on the test (Rumkita \& Yamin, 2006).

The shear box speed and the taken load could not comply with the real speed and load because of limitation of the equipment performance. By referring to previous research by (Hachiya \& Sato, 1997), the speed of the shear box was set at $100 \mathrm{~mm} / \mathrm{min}$ and 10 $\mathrm{mm} / \mathrm{min}$, whereas for the speed and normal load (N), Uzan et.al., (1978) set it as $2.5 \mathrm{~mm} / \mathrm{min}$ with load variation of $0.05 ; 0.5 ; 1.0 ; 2.5 ; 5.0 \mathrm{~kg} / \mathrm{cm}^{2}$.

The shift of the test sample on the interface layer was measured/read on the proving ring. The reading of tack coat shear strength was noticed when the test sample did not give shear resistance anymore, shown with the needle stopped on the proving ring.

\section{RESULTS AND DISCUSSION}

\subsection{Result of Shear Strength of Tack Coat on Flexible Pavement}

From the reading result of shear strength value on the proving ring, the shear strength value of each tack coat variation on tack coat distribution, as in Table 2.

Table 2. Shear strength for various tack coat variations with its distribution on flexible pavement

\begin{tabular}{llll}
\hline Variation & \multicolumn{2}{l}{ Tack coat distribution } \\
& $1 / \mathrm{m}^{2}$ & gram & $\begin{array}{l}\text { Shear force } \\
(\mathrm{kg})\end{array}$ \\
\hline $15 \mathrm{pph}$ & 0.15 & 1.2 & 329.299 \\
& 0.25 & 2.0 & 339.873 \\
& 0.35 & 2.8 & 277.940 \\
& 0.45 & 3.6 & 273.409 \\
$30 \mathrm{pph}$ & 0.55 & 4.4 & 262.835 \\
& 0.15 & 1.2 & 348.936 \\
& 0.25 & 2.0 & 487.906 \\
& 0.35 & 2.7 & 374.615 \\
$50 \mathrm{pph}$ & 0.45 & 3.5 & 315.704 \\
& 0.55 & 4.3 & 290.025 \\
& 0.15 & 1.1 & 344.404 \\
& 0.25 & 1.9 & 418.421 \\
& 0.35 & 2.7 & 410.868 \\
& 0.45 & 3.4 & 357.999 \\
\hline
\end{tabular}




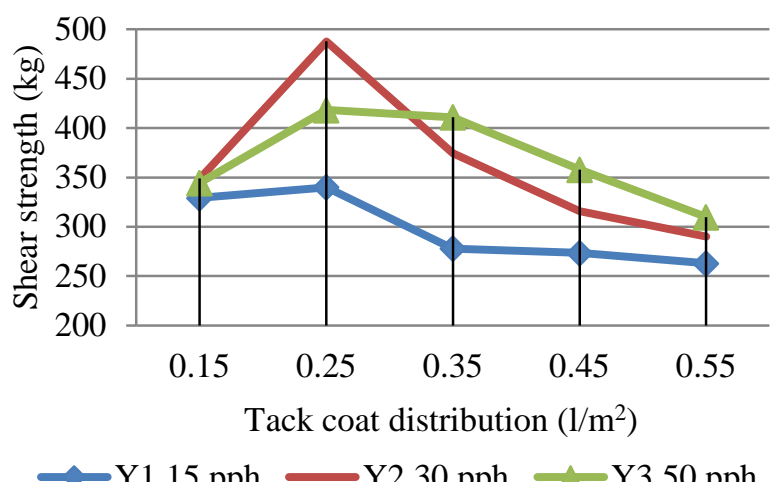

Figure 1. Relationship between shear strength and tack coat distribution on flexible pavement.

Figure 1 showed relation between shear strength and tack coat distribution on each tack coat solution variations. From the three tack coat variations, maximum shear strength was reached on $30 \mathrm{pph}$ tack coat variation, with tack coat distribution $0.25 \mathrm{~m}^{2}$ of $487.906 \mathrm{~kg}$. The relation between tack coat distributions and shear strength value is shown in Table 3.

Table 3. The balance relationship between shear strength and tack coat distribution on flexible pavement

\begin{tabular}{llll}
\hline Portion $\left(1 / \mathrm{m}^{2}\right)$ & $15 \mathrm{pph}(\mathrm{kg})$ & $30 \mathrm{pph}(\mathrm{kg})$ & $50 \mathrm{pph}(\mathrm{kg})$ \\
\hline 0.15 & 336.550 & 421.442 & 394.253 \\
0.25 & 316.611 & 392.440 & 381.262 \\
0.3198 & 302.693 & 372.196 & 372.195 \\
0.32 & 302.653 & 372.138 & 372.169 \\
0.35 & 296.671 & 363.437 & 368.272 \\
0.45 & 276.732 & 334.435 & 355.281 \\
0.55 & 256.793 & 305.432 & 342.290 \\
\hline
\end{tabular}

It could be seen that the balance relation between tack coat shear strength with tack coat distribution was reached on $30 \mathrm{pph}$ and $50 \mathrm{pph}$ variations on portion of $0.3198 \mathrm{l} / \mathrm{m}^{2}$ with shear strength of $372.196 \mathrm{~kg}$. As for the 15 pph variation, the existing data did not show the balance relation with $30 \mathrm{pph}$ and $50 \mathrm{pph}$ variations. Graphic on balance relationship between shear strength and tack coat distribution is shown in Figure 2.

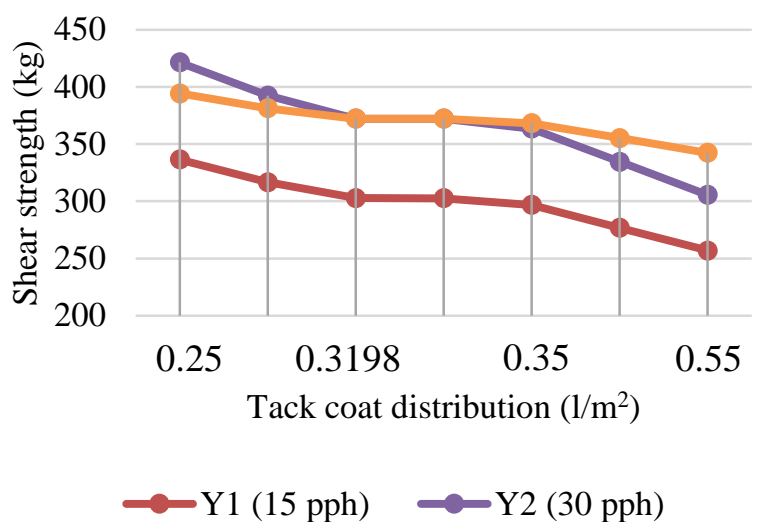

Figure 2. Balance relationship between shear strength and tack coat distribution on flexible pavement.

\subsection{Result of Tack Coat Shear Strength on Composite Pavement}

Test of shear strength on composite pavement resulted on shear strength for each tack coat variations on tack coat distribution, as shown in Table 4. From three of the tack coat variations for composite pavement, the result was the maximum shear strength value was $315.704 \mathrm{~kg}$ on tack coat distribution of $0.35 \mathrm{l} / \mathrm{m}^{2}$ for 15 pph tack coat variation. Generally, it could be seen that the $15 \mathrm{pph}$ and $50 \mathrm{pph}$ tack coat solution variation were on portion ranged from $0.31 / \mathrm{m}^{2}$ to $0.4 \mathrm{l} / \mathrm{m}^{2}$, as shown in Figure 3.

Table 4. Shear strength for various tack coat variations with its tack coat distribution on composite pavement

\begin{tabular}{llll}
\hline \multirow{2}{*}{ Variation } & \multicolumn{2}{l}{ Tack Coat Distribution } & $\begin{array}{l}\text { Shear } \\
\text { Force } \\
(\mathrm{Kg})\end{array}$ \\
\cline { 2 - 3 } & $1 / \mathrm{m}^{2}$ & gram & 246.219 \\
& 0.15 & 1.2 & 283.983 \\
$15 \mathrm{pph}$ & 0.25 & 2.0 & 315.704 \\
& 0.35 & 2.8 & 274.919 \\
& 0.45 & 3.6 & 220.540 \\
& 0.55 & 4.4 & 302.109 \\
$30 \mathrm{pph}$ & 0.15 & 1.2 & 249.240 \\
& 0.25 & 2.0 & 247.729 \\
& 0.35 & 2.7 & 243.198 \\
$50 \mathrm{pph}$ & 0.45 & 3.5 & 212.987 \\
& 0.55 & 4.3 & 276.430 \\
& 0.15 & 1.1 & 270.388 \\
& 0.25 & 1.9 & 296.067 \\
& 0.35 & 2.7 & 291.535 \\
\hline
\end{tabular}




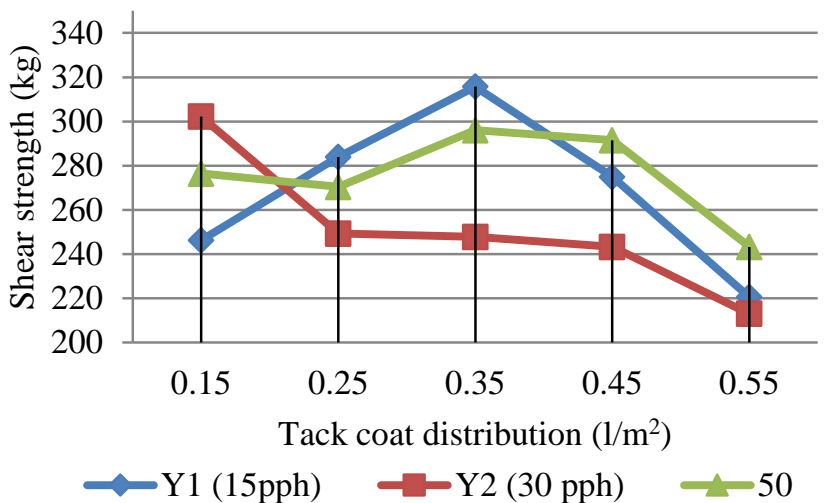

Figure 3. Relationship between shear strength and tack coat distribution on composite pavement.

The balance between tack coat distribution and the composite pavement shear strength value could be seen in Table 5.

Table 5. The balance relation between shear strength and tack coat distribution on composite pavement

\begin{tabular}{llll}
\hline $\begin{array}{l}\text { Portion } \\
\left(\mathrm{l} / \mathrm{m}^{2}\right)\end{array}$ & $\begin{array}{l}15 \mathrm{pph} \\
(\mathrm{kg})\end{array}$ & $\begin{array}{l}30 \mathrm{pph} \\
(\mathrm{kg})\end{array}$ & $\begin{array}{l}50 \mathrm{pph} \\
(\mathrm{kg})\end{array}$ \\
\hline 0.15 & 280.407 & 287.910 & 284.587 \\
0.16 & 279.802 & 286.067 & 284.133 \\
0.17 & 279.198 & 284.224 & 283.680 \\
0.174 & 278.957 & 283.487 & 283.499 \\
0.18 & 278.594 & 282.381 & 283.227 \\
0.2 & 277.386 & 278.696 & 282.321 \\
0.21 & 276.781 & 276.853 & 281.868 \\
0.211 & 276.721 & 276.668 & 281.822 \\
0.25 & 274.365 & 269.481 & 280.055 \\
0.35 & 268.322 & 251.053 & 275.523 \\
0.45 & 262.280 & 232.624 & 270.992 \\
0.55 & 256.238 & 214.195 & 266.460 \\
\hline
\end{tabular}

On Figure 4, it could be seen clearly that the balance relation of $15 \mathrm{pph}$ and $30 \mathrm{pph}$ tack coat solution variations was at portion of $0.211 \mathrm{1} / \mathrm{m}^{2}$ with shear strength of $276.721 \mathrm{~kg}$. As for $30 \mathrm{pph}$ and $50 \mathrm{pph}$, it was at a portion of $0.1741 / \mathrm{m}^{2}$ with shear strength of $283.487 \mathrm{~kg}$. The $15 \mathrm{pph}$ and $50 \mathrm{pph}$ tack coat solution variations did not have balance relation.

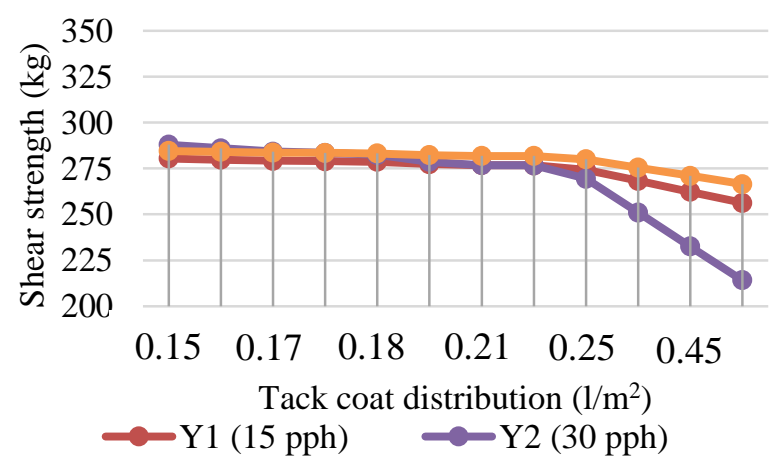

Figure 4. Balance between shear strength and tack coat distribution on composite pavement.

\subsection{Direct Shear Test Equipment}

On the measurement for tack coat shear strength on asphalt sample, the equipment used was the modified direct shear equipment. This direct shear equipment was similar with the direct shear equipment used to obtain parameter of soil shear strength. The modifications conducted were on the proving ring base and the test sample base, in which it was adjusted to the test sample size. This direct shear test equipment was operated manually.

\section{CONCLUSIONS}

From aforementioned research results and discussions, several conclusions could be made as follows:

a) The highest shear strength for flexible pavement was reached on the $30 \mathrm{pph}$ tack coat solution composition; and for composite pavement, it was reached on $15 \mathrm{pph}$ tack coat solution composition.

b) The tack coat distribution of $1 / \mathrm{m}^{2}$ gave the highest shear strength value on flexible pavement; while for the composite pavement, the highest shear strength value was reached at the tack coat distribution of $0.35 \mathrm{l} / \mathrm{m}^{2}$.

c) On flexible pavement, the $30 \mathrm{pph}$ and $50 \mathrm{pph}$ tack coat variations reached balance relation, in which the tack coat distribution of $0.31981 / \mathrm{m}^{2}$ had an almost similar shear strength; while on composite pavement, balance relation between shear strength and tack coat distribution was reached by $15 \mathrm{pph}$ and $30 \mathrm{pph}$ tack coat solution variations on the portion of $0.211 \mathrm{l} / \mathrm{m}^{2}$, also by $30 \mathrm{pph}$ and $50 \mathrm{pph}$ tack coat solution variations on portion of 0.174 $1 / \mathrm{m}^{2}$.

d) Based on the equipment performance during the research, the modified direct shear test equipment could be used as a method to measure tack coat shear strength on flexible pavement and composite pavement.

\section{REFERENCES}

AASHTO, 1970. AASHTO M 20 Standard Specification for Penetration-Graded Asphalt Cement, Washington D.C.: AASHTO (American Association of State Highway and Transportation Officials).

AASHTO, 2016. AASHTO M 140 Standard Specification for Emulsified Asphalt, Washington D.C.: AASHTO (American Association of State Highway and Transportation Officials).

Afrilianto, E., 2007. Pengukuran Laboratoris Kuat Tekan Lapisan Tack Coat Dengan Menggunakan Alat Tekan Marshall Yang Dimodifikasi, Bandung: s.n. 
Directorate General of Highways, 2013. Manual Desain Perkerasan Jalan No.02/M/BM/2013, Jakarta: Directorate General of Highways, Ministry of Public Works.

Hachiya, Y. \& Sato, K., 1997. "Effect of tack coat on bonding characteristics at interface between asphalt concrete layers," Proceedings of 8th International Conference on Asphalt Pavements, 1, 349-362.
Rumkita, I. \& Yamin, A., 2006. Pengaruh Curing Time Dan Pengaruh Air Pada Lapisan Ber-Tack Coat Terhadap Kinerja Tahanan Geser Pada Interface Lapisan Beraspal. Jurnal Jalan - Jembatan, 23(2).

Uzan, J., Livneh, M. \& Eshed, Y., 1978. Investigation of Adhesion Properties between Asphaltic-Concrete Layers. Asphalt Paving Technology, Volume 47, pp. 495-521. 